Available online at: http://proceeding.rsfpress.com/index.php/pss/index

LPPM UPN “Veteran" Yogyakarta Conference Series

Proceeding on Political and Social Science (PSS)

Volume 1 Number 1 (2020): 248-256

\title{
Evaluation of Usage Behaviour of IOT-Based Aquaculture Technologies
}

\author{
Mangaras Yanu Florestiyanto, Panji Dwi Ashrianto, Bambang Yuwono, Hidayatulah \\ Himawan \\ Universitas Pembangunan Nasional Veteran Yogyakarta \\ Email Address mangaras.yanu@upnyk.ac.id; Email Address : \\ panjidwiashrianto@upnyk.ac.id; Email Address bambangy@upnyk.ac.id; \\ Email Address if.iwan@upnyk.ac.id
}

\begin{abstract}
The production of aquaculture products still needs to be increased to match marine products. One of the problems that cause cultivation fishery production is not optimal is that it has not utilized modern technology. Cultivators still use traditional methods and technologies in cultivation. One of the contemporary technologies that can support aquaculture is Automation Technology and the Internet of Things (IoT). This research will develop an IoT-based technology, which is a system to help fish maintenance management. This system is based on a static robot that will monitor the condition of pond water quality and feed the fish automatically, which can be controlled remotely by adopting an IoT architecture. Furthermore, an evaluation of cultivators/farmers regarding Adopting Intention (AI) of this technology. The evaluation model adopted the model proposed by (Kao et al., 2019). This model explores the direct influence of perceived usability, performance expectations, perceived technology usefulness, network externality, user creativity, and domain-specific information on intent and their indirect impact on user behavior.
\end{abstract}

Keywords: Iot, Adopting Intention, Usage Behavior

\section{INTRODUCTION}

This is an open access article under the CC-BY-NC license.

Indonesia has about 17,504 islands with a coastline of 99,093 km (Ministry of Maritime Affairs and Fisheries, 2017). Approximately $62 \%$ of the territory of Indonesia is sea and water; as confirmed by data from the Ministry of Maritime Affairs and Fisheries, the land area is 1.91 million $\mathrm{km}^{2}$. The water area, on the other hand, is 6.32 million $\mathrm{km}^{2}$. With such a landscape, Indonesia undoubtedly has the potential for extraordinary marine resources, especially in the fisheries field.

The trade balance rose by 7.42 percent from USD 3.403 billion in 2016 to USD 3.655 billion in 2017. However, the figure is still dominated by marine products (Zulkarnain, Purwanti, and Indrayani, 2013). To be able to keep up with marine products, the production of 
cultivated products also needs to be increased. One of the barriers that prevent the development of aquaculture from being optimal is that it has not used modern technology. Cultivators also use conventional cultivation methods and technologies (CST, Djunaidah, and Sinaga, 2019; Ichtifa, Wiryati, and Anas, 2019). Automation Technology and the Internet of Things ( IoT) (Ma and Ding, 2018; Niswar et al., 2018; Hsu et al., 2019; Lafont et al., 2019) are among the latest technologies that can support aquaculture.

IoT technology itself has grown rapidly and is evolving very quickly (Mohamad Noor and Hassan, 2019) in different fields. IoT is a philosophy that seeks to maximize the advantages of ever-connected Internet connectivity. As for its features, such as data sharing, remote control, and so on, including real-world objects. For example, food, electronics, collectibles, any equipment, even living objects that are all linked to local and global networks via embedded sensors and always on.

Farming fish needs routine maintenance to remain safe and increase its yield. This regular maintenance can be assisted by the use of IoT and automation technologies. Technology has a significant impact, both directly and indirectly, on human routines. Given the limited use of modern technology, in particular IoT in aquaculture, this research will improve IoT-based technology, which is a device to help manage fish farming. This device will track the quality of the water in the pond and feed the fish automatically, which can be remotely controlled by the IoT architecture. In addition, the assessment of cultivators/cultivators related to the Adopting Intention (AI) of this technology, namely the willingness of cultivators/cultivators to embrace and use the device for the maintenance of fish.

\section{LITERATURE REVIEW}

In today's completely integrated age, IoT affects people's everyday lives because of improved comfort and productivity in carrying out activities and tasks. Therefore, developing an IoT-based framework and understanding the factors that affect user intentions and actions when implementing and using IoT is a fascinating and important question. Many studies have already been performed on the use of IoT in aquaculture (Africa et al., 2017; Raju and Varma, 2017; Abinaya, Ishwarya, and Maheswari, 2019; Budiman, Rivai and Nugroho, 2019). There have also been several user behavior studies in the adoption and usage of IoT-based technology, as was done by (Elsaadany and Soliman, 2017). Elsaadany and Soliman carried out an awareness assessment in the implementation of IoT in the educational environment, and the results of his research concluded that the level of awareness in the academic environment was significant in the application of IoT-based technology. IoT is believed to be able to aid in different aspects of life.

Hsu and Lin in (Hsu and Lin, 2016), conducted an empiric analysis of the customer acceptance of IoT services, in which they argued that consumers are interested in the advantages of using IoT services, and IoT service providers must highlight those advantages and the importance of using their services. In addition, IoT service providers must understand the importance of compatibility and ensure that their offerings are consistent with consumer values and lifestyles. 
One of the studies that evaluated agriculture was carried out by (Mwangi and Kariuki, 2015), which resulted in recommendations to increase the acceptance of technology by farmers, and it is necessary for policymakers and the latest technology providers to understand the needs of farmers and their desire to accept technology to make this happen.IoT studies to support aquaculture are relatively uniform. These studies are oriented towards water quality monitoring. In this research, the development of IoT is not only for monitoring water quality but also includes automatic feeding management according to a predetermined schedule. When the system has been successfully developed, the next challenge is the willingness of aquaculture cultivators/farmers to take advantage of this technology.

\section{RESEARCH METHODOLOGY}

The research method used is a qualitative method of facilitating quantitative (Bryman, 2016). A qualitative approach is needed in the development of an IoT-based fish farming management system, from a qualitative approach to a quantitative approach to measure the readiness of aquaculture cultivators/farmers in adopting IoT-based fish farming management system technology. Measuring behavior in adopting IoT-based technology is based on a model that has been proposed by (Kao, Nawata, and Huang, 2019). Kao et al. developed a new model to evaluate user intentions in adopting IoT-based fitness tracking gadget technology. The model developed is an integration model of TRA, TPB, TAM, DOI, TRI, and UTAUT with TAM as the basic model. The model proposed in this study to measure the level of adoption intention is as follows.

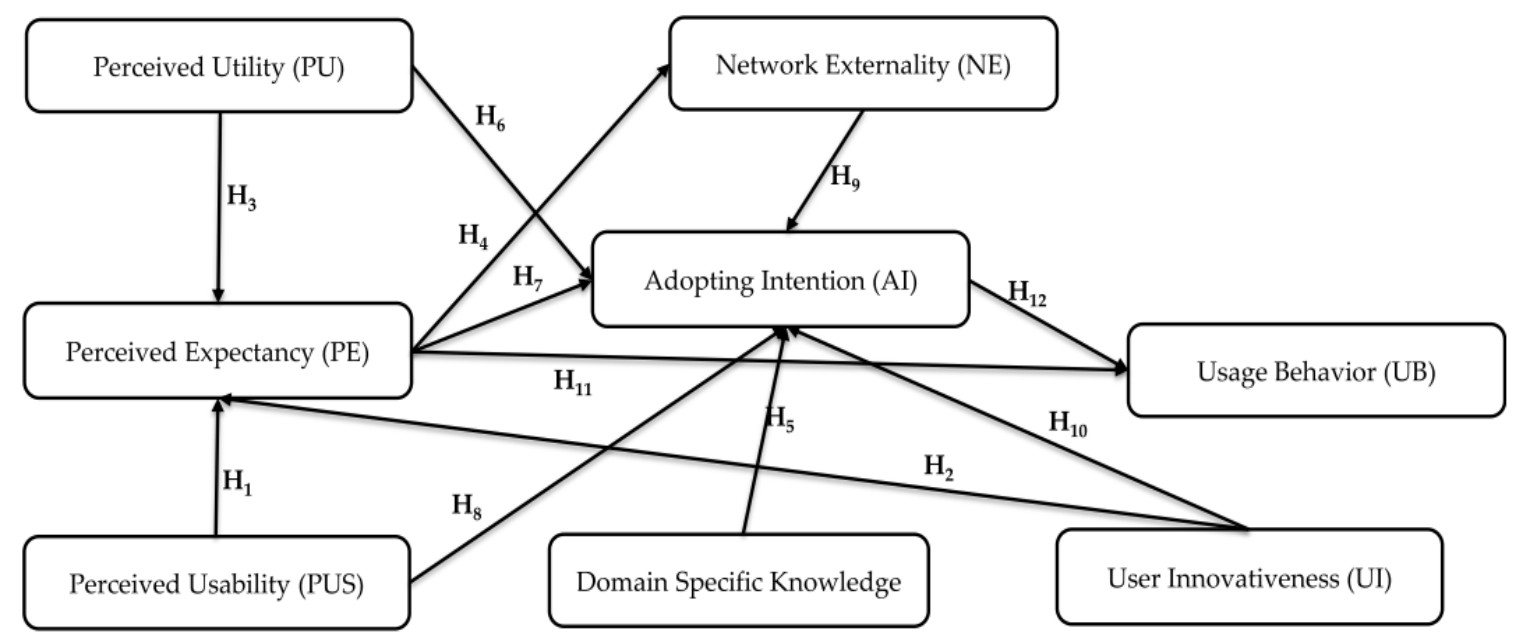

Figure 1 The evaluation model and hypotheses

\section{III.1. Sample}

A web-based questionnaire survey was conducted in Yogyakarta, Indonesia, to test the assumptions. In order to gather information from the respondents, participants will be recruited over a period of one month via Facebook and WhatsApp, and Telegram messages with a wide range and tolerance to such data collection marketing campaigns. The letter described the intent of the proposed investigation included a web link to the form of the research study. The questionnaire contained reminders to ensure that all research questions 
were answered by the participants, minimizing the level of inaccurate submissions. Preventing repetitive answers, redundant e-mail accounts, and IP addresses have been removed. The survey questionnaire offered 68 available answers. All the respondents were male. The proportion of participants $(56 \%)$ were between the ages of 20 and 29 .

\section{III.2. Measurement Development}

The research study used questionnaires: the demographic information and the construction of the objects. Assessments adapted from previous research with alteration to suit the context in this study have been used to create scales for the measurement of constructs. Each item was evaluated on a five-point Likert scale, varying from "strongly disagreed" (1) to "strongly agreeable" (5).

\section{FINDING AND DISCUSSION}

\section{IV.1. Descriptive Statistics}

Table 1 offers descriptive statistics. On average, the participants responded directly to the study constructs (most levels surpassed 3).

Table 1.Descriptive statistics (means and standard deviation)

\begin{tabular}{|c|c|c|}
\hline$n=68$ & Mean & Standard Deviation \\
\hline Perceived usability & 4.235 & 0.565 \\
\hline Performance expectancy & 4.314 & 0.494 \\
\hline Perceived technology utility & 4.137 & 0.478 \\
\hline Network externality & 4.230 & 0.501 \\
\hline User innovativeness & 4.049 & 0.433 \\
\hline Domain-specific knowledge & 4.029 & 0.522 \\
\hline Adopting intention & 4.039 & 0.439 \\
\hline Usage behavior & 3.711 & 0.633 \\
\hline
\end{tabular}

\section{IV.2. Measurement Model}

After Hair et al. (Hair et al., 2017), we tested the reliability of the measuring instruments through testing its loading factors, Cronbach's alpha, and composite reliability (CR) in the convergent validity. As shown in Table 2, the loading of all instruments was higher than 0.7 and was significant. In the same period, Cronbach's alpha and CR were more than 0,701, at or above the suggested minimum of 0,70 based on (Hair et al., 2017), proving the reliability of the measuring instruments and designs. Also, as shown in Table 2, we assessed the converging validity of the model using the derived average variance (AVE) because most AVE values were more than the specified amount of 0.5 , indicating the converging validity of the constructs. 
Table 2.Outer Model Results

\begin{tabular}{|c|c|c|c|c|}
\hline Construct & Loading & $\begin{array}{l}\text { Cronbach's } \\
\text { Alpha }\end{array}$ & $\begin{array}{l}\text { Composite } \\
\text { Reliability }\end{array}$ & AVE \\
\hline Adopting intention & & 0.933 & 0.968 & 0.937 \\
\hline AI2 & 0.964 & & & \\
\hline AI3 & 0.972 & & & \\
\hline Domain-specific knowledge & & 0.806 & 0.911 & 0.836 \\
\hline DSK1 & 0.894 & & & \\
\hline DSK2 & 0.934 & & & \\
\hline Network externality & & 0.704 & 0.828 & 0.616 \\
\hline NE1 & 0.831 & & & \\
\hline NE2 & 0.714 & & & \\
\hline NE3 & 0.805 & & & \\
\hline Performance expectancy & & 0.897 & 0.936 & 0.831 \\
\hline PE1 & 0.927 & & & \\
\hline PE2 & 0.948 & & & \\
\hline PE3 & 0.858 & & & \\
\hline Perceived technology utility & & 0.701 & 0.833 & 0.626 \\
\hline PU1 & 0.890 & & & \\
\hline PU2 & 0.747 & & & \\
\hline PU3 & 0.726 & & & \\
\hline Perceived usability & & 0.829 & 0.899 & 0.748 \\
\hline PUS1 & 0.931 & & & \\
\hline PUS2 & 0.861 & & & \\
\hline PUS3 & 0.797 & & & \\
\hline Usage behavior & & 0.752 & 0.849 & 0.654 \\
\hline UB1 & 0.768 & & & \\
\hline UB2 & 0.927 & & & \\
\hline UB3 & 0.717 & & & \\
\hline User innovativeness & & 0.843 & 0.925 & 0.860 \\
\hline UI1 & 0.955 & & & \\
\hline UI2 & 0.900 & & & \\
\hline
\end{tabular}

Finally, the discriminant validity was tested based on the Fornell-Larcker criteria (Table 3) where the square roots of the AVE were more generous than the critical correlations, thereby confirming discriminant validity (Hair et al., 2017).

Table 3.Fornell-Larcker Criterion

$\begin{array}{lllllllll}\text { Construct } & \text { AI } & \text { DSK } & \text { NE } & \text { PE } & \text { PU } & \text { PUS } & \text { UB } & \text { UI } \\ \text { Adopting intention (AI) } & 0.968 & & & & & & & \\ \text { Domain-specific knowledge (DSK) } & 0.863 & 0.914 & & & & & \\ \text { Network externality (NE) } & 0.562 & 0.557 & 0.785 & & & & & \\ \text { Performance expectancy (PE) } & 0.450 & 0.419 & 0.545 & 0.912 & & & \\ \text { Perceived technology utility (PU) } & 0.302 & 0.376 & 0.431 & 0.786 & 0.791 & & \\ \text { Perceived usability (PUS) } & 0.678 & 0.768 & 0.555 & 0.574 & 0.607 & 0.865 & \end{array}$




$\begin{array}{lllllllll}\text { Usage behavior (UB) } & 0.590 & 0.683 & 0.445 & 0.165 & 0.174 & 0.473 & 0.809 & \\ \text { User innovativeness (UI) } & 0.554 & 0.750 & 0.443 & 0.083 & 0.279 & 0.459 & 0.650 & 0.928\end{array}$

\section{IV.3. Structural Model}

We used SmartPLS v3.3.2 with the default bootstrap process variables to test the hypotheses in our conceptual scheme. Figure 2 illustrates the results of the structural model.

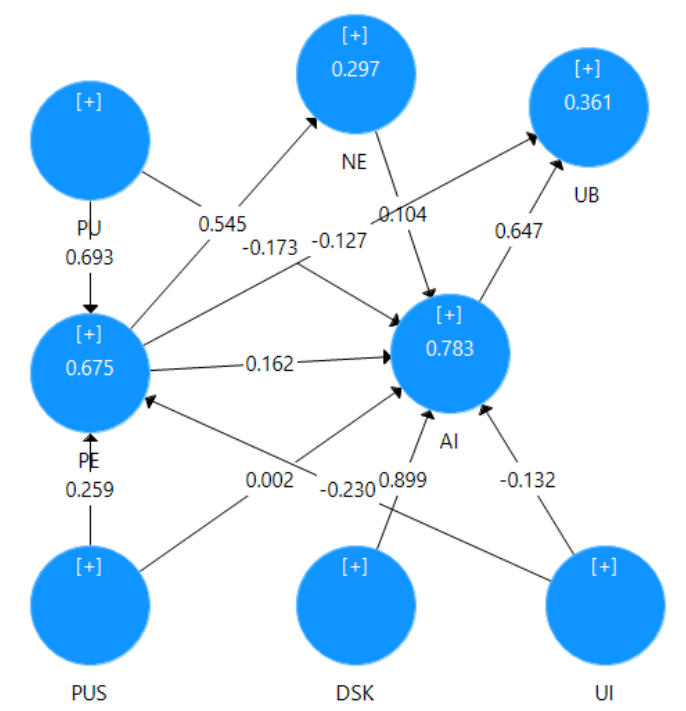

Figure 2 Results of the proposed model

The research model was tested by evaluating the t-values, the p-values, the standardized beta-value coefficient, and the coefficient of determination (R2 value). The hypothesis was verified when the $t$-value was greater than the upper bound (i.e. $t \geq 1.96, p \leq 0.05$ ) and was marginally verified when the $t$-value was greater than the upper bound (i.e. $t \geq 1.67, p \leq 0.10$ ) using a two-size test.

Figure 2 shows that the results support six of the twelve hypotheses. With regard to the context of the adopting intention, the most potent effect of domain-specific knowledge on the adopting intention $(\beta=0.899, \mathrm{p}<0.05)$, confirms H5. However, the effect of performance expectancy, network externality, and perceived usability on adopting intention was weak and non-significant, rejecting $\mathrm{H} 7, \mathrm{H} 9$, and $\mathrm{H} 8$. Also, $\mathrm{H} 6$ and $\mathrm{H} 10$ were rejected because perceived technology utility and user innovativeness had a negative impact on adopting intention.

Meanwhile, on performance expectancy, the influence of perceived technology utility on performance expectancy was the highest and most significant $(\beta=0.693, p<0.05)$, supplemented by perceived usability $(\beta=0.259, \mathrm{p}<0.05)$. However, user innovativeness has a negative and significant impact on performance expectancy $(\beta=-0.230, p<0.05)$. H3 and $\mathrm{H} 1$ are thus supported, and $\mathrm{H} 2$ is refused.

With respect to the antecedent of network externality, the impact of performance expectancy on network externality was positive and significant $(\beta=0.545, \mathrm{p}<0.05)$, confirming H4. 
Last, with respect to the antecedents of usage behavior, the impact of adopting intention on usage behavior was positive and significant $(\beta=0.647, p<0.05)$, confirming H12. However, performance expectancy has a negative and non-significant impact on usage behavior $(\beta=$ $0.127, \mathrm{p}<0.05)$. H11 is, therefore rejected.

\section{III.4. Theoretical Implications}

This research extends published research by exploring the influence of perceived usability, performance expectancy, perceived technology utility, network externality, user inventiveness, domain-specific knowledge of user behavioral intentions concerning IoTbased aquaculture technology. The findings show that domain-specific knowledge is an important antecedent to the adoption of purpose and that its indirect impact on user behavior is important.

We find that the impact of performance expectancy, network externality, and perceived usability on adopting intention is not significant even though it has a positive impact, indicating that performance expectancy, network externality, and perceived usability are not preliminary adopting intentions for IoT-based aquaculture technology. Surprisingly, user innovativeness actually has a negative impact on the adoption intention of IoT-based aquaculture technology.

Then, the findings reveal that perceived technology utility, and perceived usability are essential variables that have a significant positive impact on performance expectancy for IoT-based aquaculture technology. In particular, perceived technology utility has the most substantial influence on performance expectancy, more significant than perceived usability. Meanwhile, user innovativeness has a negative impact on the performance expectancy of users on IoT-based aquaculture technology. The findings also reveal that performance expectancy is an essential factor in strengthening network externality.

\section{CONCLUSION AND FURTHER RESEARCH}

With exciting advances in emerging technology products and applications, it is hoped that IoT-based aquaculture technology devices can provide new ways to solve problems related to aquaculture productivity. Thus, the study model was empirically validated to explore behavioral variables using IoT-based aquaculture technology. Our findings show that domain-specific knowledge has a major impact on adoption intentions, which in turn drives user behavior. With limited data, many of our results are inconsistent with previous research, and further research containing more data is suggested.

\section{ACKNOWLEDGMENT}

This research was supported by Lembaga Penelitian dan Pengabdian kepada Masyarakat of Universitas Pembangunan Nasional "Veteran" Yogyakarta.

\section{REFERENCES}

Abinaya, T., Ishwarya, J. and Maheswari, M. (2019) 'A Novel Methodology for Monitoring 
and Controlling of Water Quality in Aquaculture using Internet of Things' (IoT)', in 2019 International Conference on Computer Communication and Informatics (ICCCI), pp. 14.

Africa, A. D. M. et al. (2017) 'Automated aquaculture system that regulates $\mathrm{Ph}$, temperature and ammonia', in 2017 IEEE 9th International Conference on Humanoid, Nanotechnology, Information Technology, Communication and Control, Environment and Management (HNICEM). Manila: IEEE, pp. 1-6.

Bryman, A. (2016) Quantity And Quality In Social Research. Taylor \& Francis.

Budiman, F., Rivai, M. and Nugroho, M. A. (2019) 'Monitoring and Control System for Ammonia and $\mathrm{pH}$ Levels for Fish Cultivation Implemented on Raspberry Pi 3B', Proceedings - 2019 International Seminar on Intelligent Technology and Its Application, ISITIA 2019, pp. 68-73. DOI: 10.1109/ISITIA.2019.8937217.

CST, U. O., Djunaidah, I. S. and Sinaga, W. H. (2019) 'Analisis Potensi dan Permasalahan Usaha Perikanan Budidaya di Kecamatan Bungursari Kota Tasikmalaya Provinsi Jawa Barat', Jurnal Penyuluhan Perikanan dan Kelautan, 13(1), pp. 107-119. doi: 10.33378/jppik.v13i1.119.

Elsaadany, A. and Soliman, M. (2017) 'Experimental Evaluation of Internet of Things in the Educational Environment', International Journal of Engineering Pedagogy (iJEP), 7(3), p. 50. DOI: 10.3991/ijep.v7i3.7187.

Hair, J. F. et al. (2017) A Primer on Partial Least Squares Structural Equation Modeling (PLS-SEM). Thousand Oaks: Sage Publications. Available at: https://scholar.google.com/scholar_lookup?title=Advanced+Issues + in + Partial + Least + S quares + Structural+Equation + Modeling\&author $=$ Hair, + J.F., + Jr.\&author $=$ Sarstedt,+ M.\& author $=$ Ringle, + C.M.\&author $=$ Gudergan, + S.P.\&publication $\_$year $=2017$.

Hsu, C. L., and Lin, J. C. C. (2016) 'An empirical examination of consumer adoption of Internet of Things services: Network externalities and concern for information privacy perspectives', Computers in Human Behavior. Elsevier Ltd, 62, pp. 516-527. DOI: 10.1016/j.chb.2016.04.023.

Hsu, W. W. Y. et al. (2019) 'Portable Fisheries Assistant Systems for Small Scale Fisheries Management', in 2019 IEEE Eurasia Conference on IoT, Communication, and Engineering (ECICE), pp. 10-13.

Ichtifa, N., Wiryati, G. and Anas, P. (2019) 'Potensi dan Permasalahan Perikanan Budidaya di Kecamatan Caringin Kabupaten Sukabumi Provinsi Jawa Barat', Jurnal Penyuluhan Perikanan dan Kelautan, 13(1), pp. 11-27. doi: 10.33378/jppik.v13i1.121.

Kao, Y. S., Nawata, K. and Huang, C. Y. (2019) 'An exploration and confirmation of the factors influencing adoption of IoT-based wearable fitness trackers', International Journal of Environmental Research and Public Health, 16(18). DOI: 10.3390/ijerph16183227.

Lafont, M. et al. (2019) 'Back to the future: IoT to improve aquaculture: Real-time monitoring and algorithmic prediction of water parameters for aquaculture needs', in 2019 Global IoT Summit (GIoTS), pp. 1-6.

Ma, Y. and Ding, W. (2018) 'Design of Intelligent Monitoring System for Aquaculture Water Dissolved Oxygen', in 2018 IEEE 3rd Advanced Information Technology, Electronic and Automation Control Conference (IAEAC), pp. 414-418.

Mwangi, M. and Kariuki, S. (2015) 'Factors Determining Adoption of New Agricultural 
Technology by Smallholder Farmers in Developing Countries', Issn, 6(5), pp. 22221700. Available at: www.iiste.org.

Niswar, M. et al. (2018) 'IoT-based Water Quality Monitoring System for Soft-Shell Crab Farming', in 2018 IEEE International Conference on Internet of Things and Intelligence System (IOTAIS), pp. 6-9.

Raju, K. R. S. R., and Varma, G. H. K. (2017) 'Knowledge-based real-time monitoring system for aquaculture Using IoT', Proceedings - 7th IEEE International Advanced Computing Conference, IACC 2017. IEEE, pp. 318-321. DOI: 10.1109/IACC.2017.0075.

Zulkarnain, M., Purwanti, P. and Indrayani, E. (2013) 'Analysis of Aquaculture Production Value Effect To Gross Domestic Product of Fisheries Sector in', Jurnal ECSOFiM, 1(1), pp. 52-68. 